\title{
Impact of Spirulina and Soya on Lipids, Electrolytes and Iron Status in Malnourished Children 6-59 Months in Côte D'Ivoire
}

\author{
Youan Gouanda Pascal ${ }^{1}$, Kouakou Yeboue Koffi François ${ }^{1, *}$, Yapo Adou Francis ${ }^{1}$, Koffi Allali Eugene ${ }^{2}$, \\ Ayebe Edwige Aka ${ }^{3}$, Yapi Houphouet Felix ${ }^{1}$ \\ ${ }^{1}$ Laboratory of Pharmacodynamics Biochemical, Training and Research Unit (UFR) Biosciences, \\ Felix Houphouet Boigny University, Côte d'Ivoire \\ ${ }^{2}$ Training and Research Unit (UFR), Agroforestry Faculty, Department of Biochemistry, UP Biochemistry-Microbiology, \\ Jean Lorougnon Guédé University, Côte d'Ivoire \\ ${ }^{3}$ Laboratory of Basic and Clinical Biochemistry, Pasteur Institute of Côte d'Ivoire, Côte d'Ivoire
}

Copyright $\bigcirc 2017$ by authors, all rights reserved. Authors agree that this article remains permanently open access under the terms of the Creative Commons Attribution License 4.0 International License

\begin{abstract}
This study was carried out to determine biochemical (lipids and ferritin)and electrolytes $(\mathrm{Na}, \mathrm{K}, \mathrm{Cl})$ markers in children suffering from malnutrition in Abidjan Hospital setting before and after supplementation with soya and spirulina. The study concerned a total of 195 children between 6-59 months distributed in several groups. They were evaluated for total serum cholesterol (TC), triglycerides (TG) by enzymatic method using Fully analyzer (Biosystem-Italie) and the electrolytes such as chloride, potassium and sodium concentration by flame photometry using automated analyser (Humanlyte-USA). Concerning the TG, values increased at the end of the study, but only the group having received the spirulina (group 3) supplement recorded a significant profit $(\mathrm{p}<0.001)$. It was the same for the TC for which a significant increase was observed with this same group $(\mathrm{p}<0.05)$ compared to their baseline value. There was an increase in natremia, kaliemia and chloride in all groups that were low at the start of the study compared to normal values, even though this increase was not significant. However, children kaliemia in group 3 showed a significant increase $(p<0.05)$.The intake of family foods, soya and spirulina improved lipids and electrolytes characteristics of all children under study. The diet with spirulina was the most efficient in our study.
\end{abstract}

Keywords Spirulina, Soya, Lipids, Electrolytes, Iron, Children of Côte d'Ivoire

\section{Introduction}

The term malnutrition generally refers both to undernutrition and over nutrition, but in this Study we use the term to refer solely to a deficiency of nutrition [1]. According to the World Health Organization (WHO), approximately $30 \%$ of the world's population is malnourished and 40.000 children die every day due to malnutrition and related diseases [2].Many factors can cause malnutrition, most of which relate to poor diet or severe and repeated infections, particularly in underprivileged populations. In recent years, researchers pay more attention on the low plasma total cholesterol (TC) concentration [3,4]. Other studies have shown that low plasma TC level is correlated with patients' nutritional status and it can influence these patients' prognosis exactly[5,6,7]. Triglycerides (TG) act as energy stores; thus, in absence of good nutrition, this reserve decreases. It has been known that diarrhea is more common and severe in malnourished children than normal [8]. So the serum potassium may be low due to associated diarrhea and vomiting in malnutrition while decreased sodium level is attributed to increase in extracellular fluid in plasma and a poor prognostic factor in protein energy malnutrition[9]. The same applies to chloride which is a functioning blood element just like sodium to maintain the liquids balance. Besides what precedes, it appears that malnutrition would influence the content of ferritin. The use of local products such as soya and spirulina could be an alternative to fight malnutrition markers. In fact, the choice of food solutions of rehabilitation by soya and spirulina was motivated by the supposed nutritional properties of these local products; there is also a renewed interest on behalf of the international scientific community because of their possible use as source of products with therapeutic virtues used by NGO and $\mathrm{UN}$ agencies [10]. Therefore, this work aimed to evaluate Spirulina and soy effects on serum ferritin, lipids parameters and electrolytes, in malnourished children nutritional recovery for 30 days. 


\section{Material and Methods}

\subsection{Material}

In this study, some millet porridge, soya porridge, spirulina, peanut and some oil were used in the preparation of the various dishes. The blood serum collected from children fed for 30 days by these different foods was analyzed; then an automatic biochemical analyzer (FULLY, Biosystem Italy)and an automated electrolytes analyzer were used for the analysis of various parameters studied. Biochemistry reagents and small required materials were also used.

\subsection{Methods}

\subsubsection{Patients}

We selected 195 patients (children) in General Hospital of Yopougon (GHY) and Cocody Urban Sanitary Training (Abidjan), including boys and girls aged from 6 to 59 months. Children suffering from malnutrition in this hospital were investigated in this study.

\section{Acceptance Criterions}

Children in the 6-59 months range, reached by the acute moderated malnutrition (MAM) without complications and HIV negative serology were taken into account in this study.

MAM is characterized by a weight for height Zscore varying between -3 and -2 ; children whose the brachial perimeter is between 115 and $125 \mathrm{~mm}$ were also considered as malnourished persons. The choice of our patients (malnourished) was the subject of another study already carried out by Youan et al. [11, 12].

\subsubsection{Study Design}

Regarding the biochemical profile, blood samples were obtained via venipuncture at the hospital after the children fasted for 12 hours, and allocated in suitable vials for the separation of serum. The concentrations of total cholesterol (TC) and triglycerides (TG) were determined by an enzymatic method using an automatic biochemical analyzer (Fully, Biosystem-Italie). The blood sample was also taken for serum sodium $(\mathrm{Na})$, potassium $(\mathrm{K})$ and chloride $(\mathrm{Cl})$. Immediate serum electrolytes were measured using automated electrolytes analyzer by flame photometry (Humanlyte-USA). Iron stores in the body exist primarily in the form of ferritin (SF) and can be assessed through several laboratory tests. Serum ferritin was determined by chemiluminescence in our study [13-15].

The 195 enrolled subjects were divided into three groups fed in a selective way by:

- Group 1 or control group: Family food (AF) + Millet porridge (65 children)

- Group 2: AF + Millet porridge + Soya (65 children)

- Group 3: AF + Millet porridge + Spirulina $(65$ children)

The biochemical parameters assessment included two measurements, one at beginning (D0) and the other at the end of this study (D30). The interval between these two measurements was 30 days.

\subsubsection{Index Definition Criteria}

According to the reference range for each index in our hospital laboratory, low plasma TC level is defined as TC $<$ $1.06 \mathrm{~g} / \mathrm{L}$, low serum TG level is defined as TG $<0.30 \mathrm{~g} / \mathrm{L}$, low serum ferritin level is defined as $\mathrm{SF}<30 \mu \mathrm{g} / \mathrm{L}$ for man and $\mathrm{SF}<110 \mu \mathrm{g} / \mathrm{L}$ for woman, low serum $\mathrm{Na}$ level is defined as $\mathrm{Na}<135 \mathrm{mmol} / \mathrm{L}$, low serum $\mathrm{K}$ level is defined as $\mathrm{K}<$ $3.5 \mathrm{mmol} / \mathrm{L}$, low $\mathrm{Cl}$ level is defined as $\mathrm{Cl}<95 \mathrm{mmol} / \mathrm{L}$.

\subsubsection{Statistical Analysis}

The Graph pad Prism 5.0 software was used for statistical processing; the values expressed as Mean \pm SEM from 65 children. The statistical analysis was carried out using one way analysis of variance (ANOVA) followed by Dunnet, $s$ t-test, $\mathrm{p}<0.05$ were considered as significant.

\section{Results}

\subsection{Lipid Profile}

Table 1 shows that total cholesterol and triglycerides level increased much more at the end of the study, in the case of supplementation with Spirulina; there was a significant variation of $0.35 \mathrm{~g} / \mathrm{L} \quad(\mathrm{p}<0.05)$ and $0.18 \mathrm{~g} / \mathrm{L} \quad(\mathrm{p}<0.05)$ respectively for total cholesterol and triglycerides compared to family food.

Children whose food was supplemented with soya also recovered in TC and TG, compared to the family food; the TC and TG values which were successively $1.37 \pm 0.33 \mathrm{~g} / \mathrm{L}$ and $0.63 \pm 0.26 \mathrm{~g} / \mathrm{L}$ reached $1.65 \pm 0.20 \mathrm{~g} / \mathrm{L}$ and $0.76 \pm 0.22$ $\mathrm{g} / \mathrm{L}$.

We noted that concerning $\mathrm{TC}$, the values at $\mathrm{D}_{30}$ of groups 1 and 2 are greater than the upper limit of the normal values. However, TG values are within the range of normal values for all groups. 
Table 1. Lipidsvariation in malnourished children after recovery for 30 days with diet group $\mathrm{AF}$, group $\mathrm{AF}+\mathrm{SO}$ and group $\mathrm{AF}+\mathrm{Spirulina}$.

\begin{tabular}{|c|c|c|c|c|c|c|c|c|}
\hline \multirow{2}{*}{$\begin{array}{c}\text { Lipids } \\
\text { parameters }\end{array}$} & \multirow{2}{*}{$\begin{array}{c}\text { Days of } \\
\text { sampling }\end{array}$} & \multicolumn{3}{|c|}{ Average values } & \multirow{2}{*}{$\begin{array}{c}\text { Normal } \\
\text { Value } \\
(g / L)\end{array}$} & \multicolumn{3}{|c|}{ Variation (J30-J0) } \\
\hline & & $\begin{array}{c}\text { Group } 1 \\
\text { (AF) }\end{array}$ & $\begin{array}{c}\text { Group } 2 \\
(\mathrm{AF}+\mathrm{SO})\end{array}$ & $\begin{array}{c}\text { Group } \\
3(\mathrm{AF}+\mathrm{Sp})\end{array}$ & & Group 1 & Group 2 & Group 3 \\
\hline \multirow{2}{*}{$\begin{array}{c}\text { Total } \\
\text { Cholesterol } \\
(\mathrm{g} / \mathrm{L}) \\
\end{array}$} & $\mathrm{D}_{0}$ & $1.38 \pm 0.33$ & $1.37 \pm 0.33$ & $1.15 \pm 0.38$ & \multirow{2}{*}{$1.20-1.50$} & \multirow{2}{*}{$0.27 \pm 0.18$} & \multirow{2}{*}{$0.28 \pm 0.19^{\mathrm{ns}}$} & \multirow{2}{*}{$0.33 \pm 0.17$} \\
\hline & $\mathrm{D}_{30}$ & $1.65 \pm 0.24$ & $1.65 \pm 0.20$ & $1.48 \pm 0.34$ & & & & \\
\hline \multirow{2}{*}{$\begin{array}{l}\text { Triglycerides } \\
\text { (g/L) }\end{array}$} & $\mathrm{D}_{0}$ & $0.60 \pm 0.25$ & $0.63 \pm 0.26$ & $0.60 \pm 0.19$ & \multirow{2}{*}{$0.40-1.60$} & \multirow{2}{*}{$0.10 \pm 0.07$} & \multirow{2}{*}{$0.13 \pm 0.08^{\mathrm{ns}}$} & \multirow{2}{*}{$0.18 \pm 0.11 *$} \\
\hline & $\mathrm{D}_{30}$ & $0.70 \pm 0.23$ & $0.76 \pm 0.22$ & $0.78 \pm 0.14$ & & & & \\
\hline
\end{tabular}

* $\mathrm{p}<0.05$ : Significant difference between group 1 and groups 2,3 at day 30 .

Table 2. Variation of serum electrolytes in malnourished children during the study

\begin{tabular}{|c|c|c|c|c|c|c|c|c|}
\hline \multirow{2}{*}{$\begin{array}{l}\text { Electrolytes } \\
\text { parameters }\end{array}$} & \multirow{2}{*}{$\begin{array}{c}\text { Days of } \\
\text { sampling }\end{array}$} & \multicolumn{3}{|c|}{ Average values } & \multirow{2}{*}{$\begin{array}{c}\text { Normal } \\
\text { Value } \\
(\mathrm{mmol} / \mathrm{L})\end{array}$} & \multicolumn{3}{|c|}{ Variation $\left(J_{30}-J_{0}\right)$} \\
\hline & & $\begin{array}{c}\text { Group } 1 \\
\text { ( AF) }\end{array}$ & $\begin{array}{l}\text { Group } 2 \\
(\mathrm{AF}+\mathrm{So})\end{array}$ & $\begin{array}{c}\text { Group } 3 \\
(\mathrm{AF}+\mathrm{Sp})\end{array}$ & & Group 1 & Group 2 & Group 3 \\
\hline \multirow{2}{*}{ Sodium mmol/L } & $\mathrm{D}_{0}$ & $127.6 \pm 14.0$ & $128.5 \pm 18.49$ & $\begin{array}{c}130.3 \pm \\
16.12\end{array}$ & \multirow{2}{*}{$135-145$} & \multirow{2}{*}{$6.42 \pm 8.22$} & \multirow{2}{*}{$10.36 \pm 12.73^{\mathrm{ns}}$} & \multirow{2}{*}{$11.53 \pm 11.82^{\mathrm{ns}}$} \\
\hline & $\mathrm{D}_{30}$ & $\begin{array}{c}134.0 \pm \\
13.21 \\
\end{array}$ & $139.7 \pm 9.53$ & $142.5 \pm 2.39$ & & & & \\
\hline \multirow{2}{*}{ Potassium $(\mathrm{mmol} / \mathrm{L})$} & $\mathrm{D}_{0}$ & $3.3 \pm 1.7$ & $3.2 \pm 2.7$ & $3.2 \pm 3.5$ & \multirow{2}{*}{$3.5-5$} & \multirow{2}{*}{$0.20 \pm 1.1$} & \multirow{2}{*}{$0.60 \pm 1.4^{\mathrm{ns}}$} & \multirow{2}{*}{$1.00 \pm 0.8^{*}$} \\
\hline & $\mathrm{D}_{30}$ & $3.5 \pm 2.7$ & $3.8 \pm 4.1$ & $4.2 \pm 2.3$ & & & & \\
\hline \multirow{2}{*}{ Chloride(mmol/l) } & $\mathrm{D}_{0}$ & $91.73 \pm 5.14$ & $93.53 \pm 3.95$ & $92.93 \pm 3.85$ & \multirow{2}{*}{$95-105$} & \multirow{2}{*}{$3.96 \pm 3.22$} & \multirow{2}{*}{$4.04 \pm 3.78^{\text {ns }}$} & \multirow{2}{*}{$4.13 \pm 3.29^{\mathrm{ns}}$} \\
\hline & $\mathrm{D}_{30}$ & $95.69 \pm 5.12$ & $97.58 \pm 5.18$ & $97.07 \pm 4.71$ & & & & \\
\hline
\end{tabular}

"Significant difference between group 1 and groups 2,3 on the $30^{\text {th }}$ day of treatment $(\mathrm{p}<0.05)$.

Table 3. Characterization of ferritin levels in children whose family food was supplemented with spirulina or soya

\begin{tabular}{|c|c|c|c|c|c|c|c|c|}
\hline \multirow{2}{*}{$\begin{array}{c}\text { Studied } \\
\text { parameter }\end{array}$} & \multirow{2}{*}{$\begin{array}{c}\text { Days of } \\
\text { sampling }\end{array}$} & \multicolumn{3}{|c|}{ Average values } & \multirow{2}{*}{$\begin{array}{c}\text { Normal } \\
\text { Value(mmol/L) }\end{array}$} & \multicolumn{3}{|c|}{ Variation $\left(J_{30}-J_{0}\right)$} \\
\hline & & $\begin{array}{c}\text { Group } 1 \\
\text { (AF) }\end{array}$ & $\begin{array}{c}\text { Group } 2 \\
(\mathrm{AF}+\text { So) }\end{array}$ & $\begin{array}{l}\text { Group } 3 \\
(\mathrm{AF}+\mathrm{Sp}) \\
\end{array}$ & & Group 1 & Group 2 & Group 3 \\
\hline \multirow{2}{*}{$\begin{array}{l}\text { Ferritin } \\
(\mathrm{mg} / \mathrm{L})\end{array}$} & $\mathrm{D}_{0}$ & $28.93 \pm 9.00$ & $29.84 \pm 9.48$ & $29.27 \pm 7.47$ & \multirow{2}{*}{$20-40$} & \multirow{2}{*}{$23.51 \pm 14.09$} & \multirow{2}{*}{$27.89 \pm 11.02^{\text {ns }}$} & \multirow{2}{*}{$33.04 \pm 12.75^{*}$} \\
\hline & $\mathrm{D}_{30}$ & $51.29 \pm 15.85$ & $57.73 \pm 15.64$ & $62.31 \pm 15.09$ & & & & \\
\hline
\end{tabular}

"Significant difference between group 1 and groups 2,3 on the $30^{\text {th }}$ day of treatment $(\mathrm{p}<0.05)$.

\subsection{Ionic profile}

As seen in Table 2, sodium, and chloride content increased simultaneously in the three (3) groups of children. In regards to natremia, it increased by $10.36 \pm 12.73 \mathrm{mmol} / \mathrm{L}$ for group 2 and $11.53 \pm 11.82 \mathrm{mmol} / \mathrm{L}$ for group 3 , but this increase was not significant compared to group 1, whose value was $6.42 \pm 8.22 \mathrm{mmol} / \mathrm{L}$. As for serum potassium, its value increased significantly $(\mathrm{p}<0.05)$ in comparison to those of group 3 (AF + Spirulina) compared to family food; the recovery was $1.00 \pm 0.8 \mathrm{mmol} / \mathrm{L}$. After the Spirulina, the soya allowed a better recovery of ions. It should be noted that despite this increase the parameter values are within the normal range.

\subsection{Ferritin Concentration Level}

The table 3 presents the results of ferritin at the beginning and end of the study. These results show a significant increase $(\mathrm{p}<0.05)$ of ferritin for group 3 (AF + Spirulina) compared to group 1 (AF). Ferritin in children in group 2 increased to $51.29 \pm 15.85 \mathrm{mg} / \mathrm{L}$ from baseline of $28.93 \pm$ $9.00 \mathrm{mg} / \mathrm{L}$; however, this increase was not significant compared to the family group.

According to the table, ferritin values at $\mathrm{D}_{30}$ of all groups are greater than the upper limit of the normal values.

\section{Discussion}

Malnutrition includes nutritional deficiency. Recent studies by Youan et al. indicated that children designated in this study, suffered from moderate acute malnutrition $[11,12]$. The lipid parameters (TC and TG), electrolytes levels, and serum ferritin concentration in all these same children studied were outside the normal values as recommended by WHO. Supplementation with local products such as spirulina and soya could relieve these children. The main purpose of this study is to explore the impact of local products such as soya and spirulina in improving nutritional status in children with nutritional deficiency malnutrition.

The low TC and TG values observed at Day 0 could be explained by the low lipid intake of these children. It has been shown that low cholesterol diet results in lowering circulating cholesterol levels $[16,17]$. After renutrition with soya and spirulina, children in groups 2 and 3 recovered in 
TC and TG. Spirulina contribution would have favored the increase in the TG stored in adipose tissue which constitutes an easily mobilized energy reserve. The increase in TC in these same children at the end of the study could be attributed to spirulina which is recognized as a product that not only increases HDL cholesterol levels (qualified as "good cholesterol") but also decreases those of LDL cholesterol ("bad cholesterol")[18]. Along with spirulina, the using of soya fostered also the increasing of TG and TC levels in children because of its seeds which contain $17-22 \%$ of dry weight in lipids [19].

According to Leeson and Summers[20], potassium participates in the processes that are essential to the body homeostasis, such as the acid-base equilibrium, osmotic pressure regulation, development of membrane potentials of cells (nerve transmission, muscle activity, cardiac function), activation of numerous intracellular enzymes, and glucose and amino acid absorption and transport. Nevertheless Potassium does not work alone and the correct balance between $\mathrm{Na}, \mathrm{K}$ and $\mathrm{Cl}$ is necessary for best animal performance, bone development and amino acid use [21].The electrolytes parameters $(\mathrm{Na}, \mathrm{K}$ and $\mathrm{Cl})$ of children in this study were disrupted at the beginning of this study. The hypokalemia, hyponatremia and hypochloremia in these malnourished children are thought to be due to diarrhea or vomiting that accompanies malnutrition as some authors explain $[22,23]$.The intake of spirulina and soya in groups 2 and 3 successively contributed to the rebalancing of the electrolyte status of the children after 30 days of treatment. Thus, the differences of variation obtained would be due to the supplements received. Serum ferritin concentration is an early indicator of the state of iron reserves and is the most specific indicator available for depleting iron reserves [24].

Ferritin outside the normal value observed in subjects before nutritional rehabilitation indicates that undernutrition has impoverished children in iron stores. The results reported significant improvements in the ferritin as well as iron levels at the end of the study. Spirulina supplementation was probably more effective for increasing the ferritin level in subjects with moderate malnutrition. This would be linked to the fact that Spirulina is a rich source of iron with levels equivalent to that contained in beef [25].The iron content in the Spirulina species has the ability to replete the serum iron as well as the ferritin stores.

\section{Conclusions}

At the beginning of this study, patients' lipids and electrolytes status indicated that they were suffering from moderate malnutrition. However, after 30 days of treatment, they recovered faster with spirulina and less quickly with soya and family food. It can therefore be said that in addition to spirulina, soya which is a local product contributed positively to children recovery. It should be pointed out that the use of soya as a dietary supplement could eliminate malnutrition in children between 6-18 months.

\section{REFERENCES}

[1] Blössner, Monika and de Onis, M. Malnutrition: quantifying the health impact at national and local levels. Geneva, World Health Organization, 2005. (WHO Environmental Burden of Disease Series, No. 12).

[2] WHO - World Health Organization. [Cited 2017 Dec. 9]. Avaiable from: http://www.who.int/en

[3] Kondrup, J., Rasmussen, H.H., Hamberg and O., Stanga, Z. Nutritional risk screening (NRS 2002): a new method based on an analysis of controlled clinical trials. Clinical Nutrition, 22(3): 321-336, 2003.

[4] Lin, C., Lu, Q. and Zhou, Y. Assessment of pre-operative nutrition status of general surgical patients with different methods. Chinese Journal of Clinical Nutrition, 16 (1): 12-7, 2008.

[5] Monargue-Favard, C., Garcia, I., Abidi, H., Bannier, E., Riviere, J., Drai, J. and Bonnefoy, M. Malnourished elderly people and lipid status. Journal of Nutrition Health Aging 6 (6): 370-374, 2002.

[6] Bonnefoy M., Abidi, H., Jauffret, M., Garcia, I., Surrace, J.P. and Drai, J. Hypocholesterolemia in hospitalized elderly: relations with inflammatory and nutritional status. Revue medicine interne, 23 (12): 991-998, 2002.

[7] Schupf, N., Costa, R., Luchsinger, J., Tang, M.X., Lee, J.H. and Mayeux, R. Relationship between plasma lipids and all-cause mortility in nondemented elderly. Journal of American Geriatrics Society, 53 (2): 219-226, 2005.

[8] Mubarak, A., Atta-ullah M. and Abid, H. Acute hypokalemic flaccid paralysis in malnourished children. Pak paediatrics journal, 27(4):166, 2003.

[9] Smitri, C., Agrawal, B. K., Rashmi, D. and Bhopal. Cli Serum electrolytes $(\mathrm{Na}+, \mathrm{K}+)$ Levels in Malnourished Children. Indian Journal of Clinical Biochemistry, 122, 2007.

[10] Falquet J. and Hurni J.P. Spiruline, Aspects Nutritionnels. Antenna Technologies; 41, 2006.

[11] Youan, G. P., Kouakou Y. K. F., Bamba, A., Koffi, A.E. and Yapi, H.F. Evolution of the Pronostic Inflammatory and Nutritional Index (PINI) of the Malnourished Children of 6-59 Months during Supplementation with Soya and Spirulina in Côte d'ivoire. International Journal of Biochemistry Research \& Review, 17(1): 1-8, 2017.

[12] Youan, G. P., Kouakou, Y. K. F., Koffi, A. E., Kouame, Y.Y. and Yapi, H. F. Evaluation of anthroprometric parameters, in immunology and heamatology during supplementation by soy (Glycine max) and spirulina (Arthrospira platensis) for malnourished children from six (6) to fifty nine (59) months. Asian Journal of Biochemical and Pharmaceutical Research, 4(6): 2231-2560, 2016.

[13] Bucolo, G. and David, H. Quantitative determination of serum triglycerides by the use of enzymes. Clinical Chemistry, 19(5): 476-482, 1973. 
[14] Fossati, R. and Prencipe, L. Serum triglycerides determined colorimetrically with an enzyme that produces hydrogen peroxide. Clinical Chemistry, 28(10): 2077-2080, 1982.

[15] Naito, H. K. Cholesterol. Kaplan, Clinical Chemistry. The C. V. Mosby Co St. Louis, Toronto Princeton. Pp. 437 and 1194-1206, 1984.

[16] Thuesen, L., Henricksen., L.B. and Engby, B. One-year experience with a low-fat, low-cholesterol diet in patients with coronary heart disease. American Journal of Clinical Nutrition, 44: 212-219, 1986.

[17] Rosenthal, M.B., Barnard, R.J., Rose, D.P., Inkeles, S., Hall, J. and Pritikin, N. Effect of a high-complex carbohydrate, low fat, low cholesterol diet on levels of serum lipids and estradiol. American. Journal Medicine, 78: 23-27, 1985.

[18] Juarez-Oropeza, M. A., Mascher, D., Torres-Duran, P. V., Farias, J. M. and Paredes-Carbajal, M. C. Effects of dietary Spirulina on vascular reactivity. Journal of Medicinal Food, 12(1):15-20, 2009.

[19] Lecerf, J.M. L'intérêt nutritionnel du soja. Nutrition clinique et métabolisme (9), p.137, 1995. doi: 10.1016/S0985-0562(05)80091-3.
[20] Leeson, S. and Summers, J.D. Minerals. In:. Nutrition of the chicken. Ghelph, Ca: University Books, Canada, 2001. p. 363-377.

[21] NRC - National Research Council. Nutrient requirements of poultry. $9^{\text {th }}$ ed. Washington, DC: National Academic Press; 1994.

[22] Yasmeen, M., Rehana, M., Mohammas, Hanif, G.I and Salman, S. Serum electrolytes changes in a malnourished children with diarrhea. Pakistan journal of medical science. 23, 2007.

[23] Sunil, G. and Viresh, M. clinic-biochemical spectrum of hypokalemia. Indian Pediatrics, 36:1144-1146, 1999.

[24] Wang, W., Knovich, M.A., Coffman, L.G., Torti, F.M. and Torti, S.V. Serum ferritin: Past, present and future. Biochimca et. Biophysica. Acta, 1800: 760-769, 2010. doi: 10.1016/j.bbagen.2010.03.011.

[25] Kauser, F. and Parveen, S. Effect of Spirulina as a Nutritional Supplement on Malnourished Children. The Indian Journal of Nutrition and Dietetics, 38(8): 269-272, 2001. 